\title{
EL TRAJE FALLERO: A CARRIER OF TRADITION?
}

\author{
Urszula Wilk
}

\begin{abstract}
The aim of this paper is to present and briefly analyze el traje fallero, the attire used by los falleros, the participants in the festivity of las Fallas, which takes place every year in March, in the Spanish city of Valencia. The costume, considered traditional by the administration of the festivity in an attempt to preserve Valencian heritage, is in fact a collection of different elements, not always related to the Valencian festive dressing customs that are constantly undergoing evolution. Nevertheless, it is an interesting example of the emanation of Valencian culture in the contemporary times.
\end{abstract}

Keywords: attire, dress, el traje fallero, fiesta, festival, heritage, las Fallas, tradition, Valencia

\section{INTRODUCTION}

This paper presents and analyzes the use of el traje fallero - a costume of los falleros - people who celebrate the festivity of las Fallas in Valencia, Spain. Although considered 'traditional' and frequently dated back to centuries ago, the current aspect of this attire was introduced in the 20th century. First created from a mixture of traditional farmers' celebratory garments, it was used to underline the special character of the fiesta. Later on it underwent a process of codification with the purpose of attracting attention to the feast, and nowadays, if not combined properly, it can even be a cause of exclusion from the festivity. Today it is worn not only during las Fallas, but used by los falleros throughout the whole year to highlight the special time of celebration of any fiesta that they are invited to. This sometimes causes controversy, as los falleros - because of their special attire - tend to attract attention that should be directed at the principal actors of a given fiesta. El traje fallero, creating a community within its wearers, also frequently causes an 'us - them' division in the Valencian society. It creates a discussion between those who consider it a traditional garment and a transmitter of cultural heritage, and those who state that this custom was only introduced to promulgate tourism, and that it is an invented tradition. Altogether, el traje fallero remains an important element 
of the Valencian cultural landscape and the analysis of its history and current form is a good example to present the complexity of the Valencian society.

\section{THE FESTIVAL OF LAS FALLAS}

Every year in the Spanish city of Valencia a festival of las Fallas has its finale on March 19, the feast of Saint Joseph. On that day, giant structures called fallas are reduced to ashes on the streets. This moment ends la semana fallera, the time when the city is taken over by the fiesta. During this time the community of each falla must build and present to the public their flammable monument. This event is the culmination of a yearlong preparation and finishes with la cremà, the burning of the statues. The festivity is organized by the city and its official organ directly responsible for the fiesta, Junta Central Fallera. Nevertheless, it is thousands of falleros who are the actors truly responsible for the festival. They are inhabitants of every part of the region's capital (and its surrounding cities), gathered into groups called comisiones de fallas. Members of each group partake in year-round activities in their casal faller, a place designated to be the 'home' for a falla. Their attention is centered on gathering sufficient means for the collective to participate in the festivity, as the obligation of each group, according to the set of rules that regulate the festivity, is la plantà (erecting of a falla) (Reglamento Fallero 2002: part I, art. 2.1). On an individual level, however, the falleros need to take care also of their private budget, since the attire of a member of each falla is an element of utmost importance, being a symbol of belonging to the group.

\section{EL TRAJE FALLERO}

We cannot pinpoint the exact origin of the attire considered traditionally Valencian, but its beginnings can be traced back to the 18th century and the surge of silk production in the region (Olmedo de Cerda 2014 [2003]: 122). The intense codification of the attire worn during las Fallas can be noticed especially after the Spanish Civil War. People celebrating the festivity want to mark a clear break from everyday life with several elements of the fiesta. The wearing of certain clothing, vestidura sagrada (sacred attire), as Antonio Ariño Villarroya (1992: 348) calls it, has had a meaning of interrupting the daily routine (ibid.: 347-349). 
The female dress used by falleras is currently made from silk produced in one of the many Valencian workshops. The dress has a voluminous, full length skirt and a corset. It is worn with an ornamental scarf and an apron, and handmade shoes. The falleras are obliged to wear an official emblem over their dresses during the fiesta, which indicates their rank and to which falla they belong. Women are required to wear a special hairdo with three buns, adorned with appropriate jewelry.

The official male attire was established in 1954. It is simpler, but also more diverse, as there are fewer rules that men have to follow regarding their clothing. Usually they wear a scarf (or a hat) on their head, a white shirt, a vest, pantaloons (saragüells), and rope-soled sandals on their feet (Fernández Montes 1996: 613). The obligatory element is a faja (a sash worn as a belt), which indicates the rank of the person wearing it. Sometimes they also wear a manta (a piece of coarse cloth that was formerly used as a blanket and was transformed into an ornamental piece of clothing) (Fig. 1) (more on male historic Valencian attire see, e.g., Ferrandis Mas 1983).

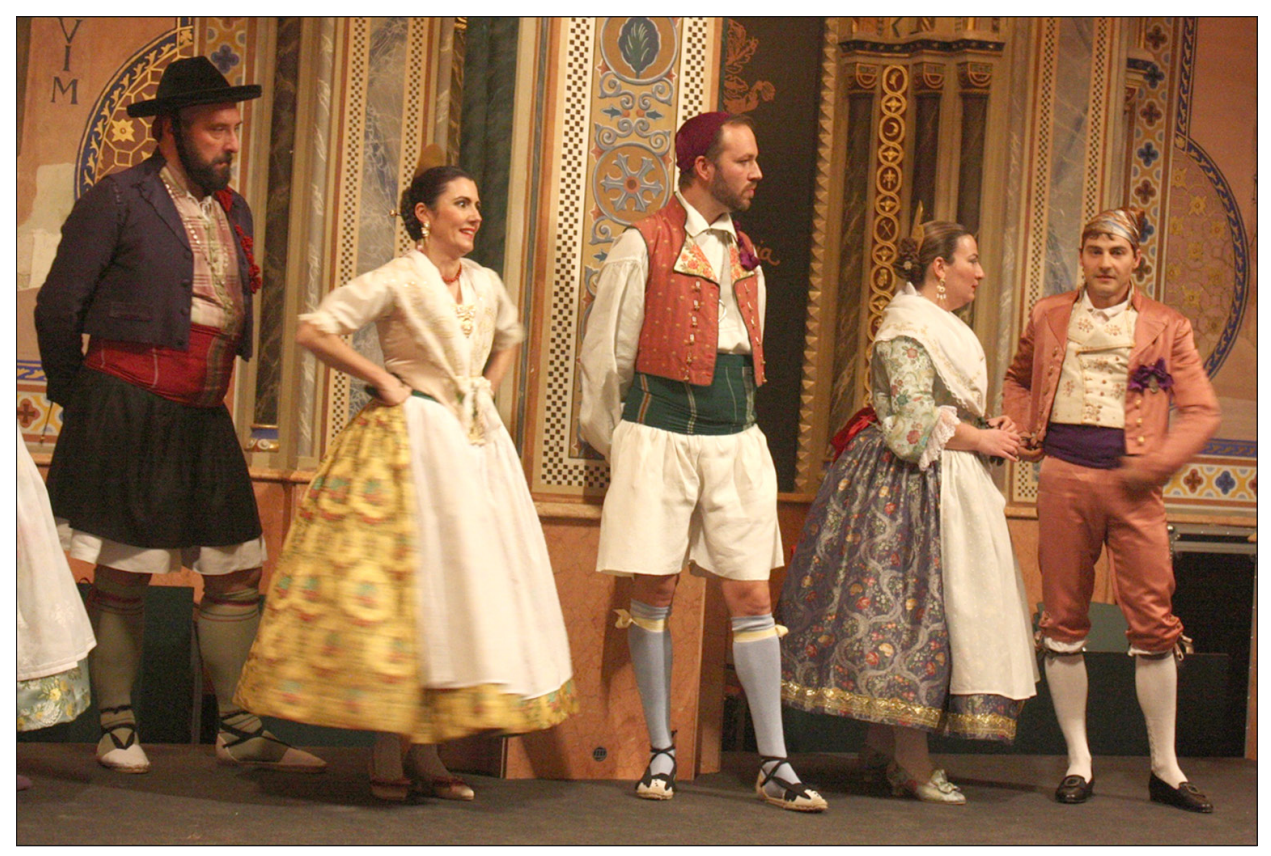

Figure 1. Recreation of three types of male 18th-century attire. Photograph by Urszula Wilk 2015. 
The falleros also use a work suit called blusón (a shirt with an emblem of the falla), which is officially considered male attire, although it is worn during unofficial occasions by both sexes.

The rules regarding the attire of the falleros are stated in an official document. The second chapter of article 64 in the current official regulations of el traje fallero for the festivity states:

1. With the purpose of giving the highest splendor to the acts and parades related to las Fallas, the commissions will watch over the attire used during las Fallas, as it should be a traditional Valencian attire fallero, with differentiation between that used by a man and a Valencian fallera woman:

a) the fallero will use an attire instituted during the IV Congreso General Fallero or any other Valencian traditional garment;

b) the fallera should wear a traditional Valencian garment.

2. The use of any attire that does not follow the rules of the traditional dress code fallero mentioned above is strictly prohibited, as is using the male attire by falleras, during official acts, regardless of the position they occupy. To specify, el blusón or blusa is considered male attire. ${ }^{1}$ (Reglamento Fallero 2002)

Nowadays, these rules cause certain discussion. The first issue is the meaning of the word 'traditional', especially with the female attire, as it could be seen as an element of invented tradition that "inculcates certain... norms of behavior by repetition, which automatically implies a continuity with the past" (Hobsbawm \& Ranger 1992 [1983]: 1). The current fashion of wearing dresses by the falleras blends together different epochs, as stated by María Victoria Liceras Ferreres (2011). This expert on clothing highlights that the two different styles of dress - the official and the historic - should be differentiated, to avoid the falleras getting excluded from the festivities for wearing 'inappropriate' garments only because they wear a historic dress or hairstyle. Liceras Ferreres points to several differences. For example, the falleras tend to overuse embroidery in their 'traditional' attire, while the earlier designs were simpler, as silk was already luxurious enough. The neckline of the dress currently shows more cleavage, which earlier on was concealed with a scarf that now has only ornamental meaning (as does the apron, used before simply to avoid tarnishing the dress). The skirt extended only to the ankles and had a natural flow because of the layers. It underwent numerous changes throughout history; for example, in the 1960s it was shortened to knee length (with the mini dress in fashion), and today it is back to full length, and it is much more voluminous than the historic one. The hairdo with three buns is of romantic origin; before 
that women used to wear only one. As a whole, the current dresses, made of luxurious silk, are reminiscent of the attires of the 18th and 19th centuries, but at the moment, for example, one bun is considered inappropriate (for more on the historic Valencian attire see, e.g., Liceras Ferreres 2011; Puerta Escribano 2002). Another clash pointed out by Liceras Ferreres is caused by frequent pairing of a fallero, whose clothes resemble more those historically worn by the Valencian farmers, and a fallera, whose dress, although popularly called la labradora, has little to do with that of a farmer and has more in common with that of the higher class (Figs. 2, 3).

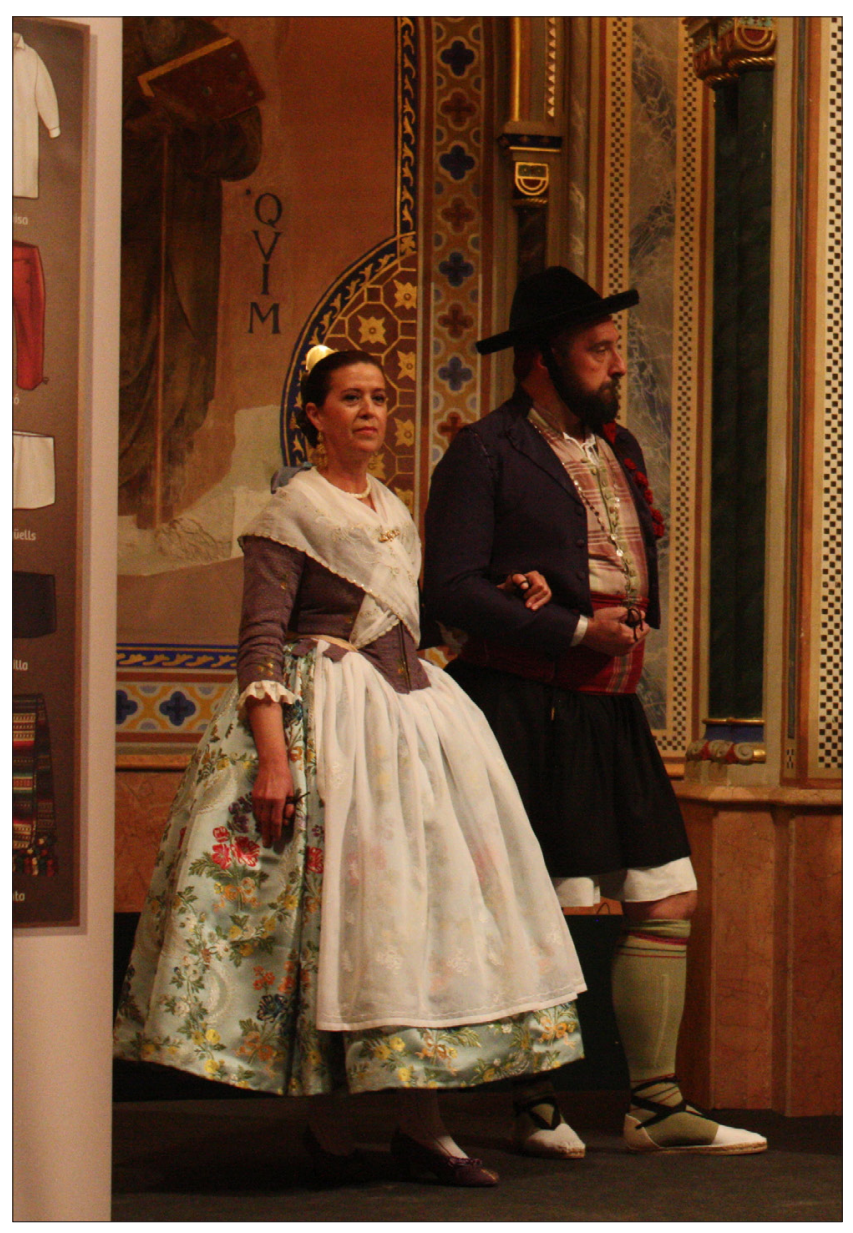

Figure 2. Recreation of female 18th-century attire. Photograph by Urszula Wilk 2015. 


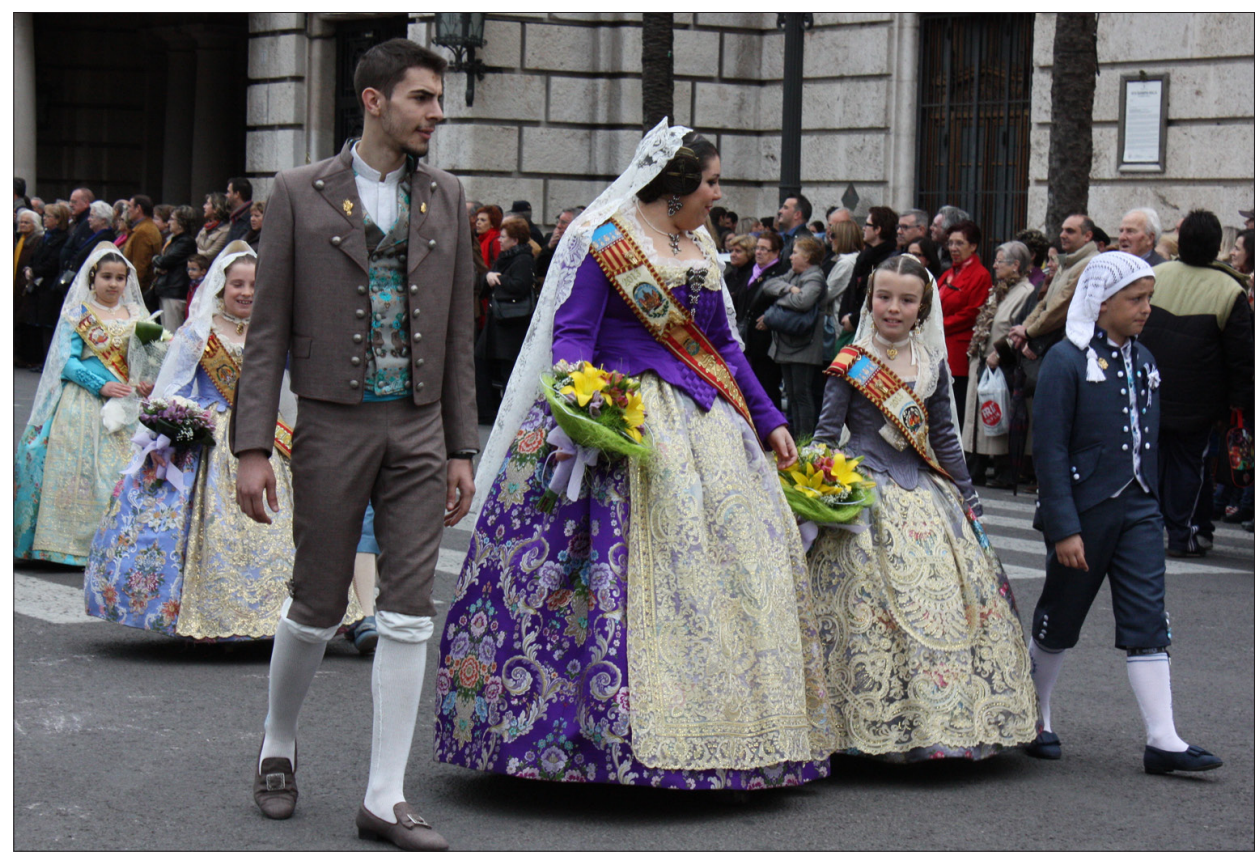

Figure 3. Modern fallera attire. Photograph by Urszula Wilk 2013.

\section{WOMEN IN FALLAS}

An interesting subject is the role of women in their comisiones de fallas. Although earlier it was not possible, nowadays a woman can be an active member in charge of a comisión de falla, taking on a position of la presidenta (the president). Nevertheless, as already mentioned above, the regulations of the attire still divide the clothing clearly between the male and female, prohibiting women to wear el blusón on official occasions. At the same time, this item of clothing is most frequently used by the falleros, both male and female, during all occasions considered unofficial.

With the possibility of acting as a president of their falla, most women still prefer to act as falleras, although this part does not imply any active role in the festivity. In the 1930s there was an important change imposed on the organization of las Fallas festival, and a figure of la Fallera Mayor was created. The unification of the festivity in that time was directly related to the opportunity of 
bringing tourists into the city by showing the folkloric presentation of the local culture to the public. However, the part of la Fallera Mayor has been mainly ornamental; it does not possess any real power except for being a representation or even a personification of the festivity.

The creation of this figure with an honorific part as an emanation of a symbol of a commission fallera, was first carried out in 1931, with the election of the first woman to be the Reina de las Fallas (the Queen of las Fallas) won by Angeles Algarra. She was, as highlighted by Ariño Villarroya (1990: 756), not la Fallera Mayor, and was not dressed as la Valenciana for the occasion. From that moment on, the associations started to elect their beauty queens and that led to the creation of the role of la Fallera Mayor.

Nowadays, the official regulations state:

La Fallera Mayor will be the only woman who will execute the honorary representation part of the Comisión de Falla during internal and official acts. She will be appointed exclusively by Junta Central, and will be given preferential treatment established by the protocol during all actions of la Comision. She will use a distinction of the traditional sash made in the colors of the national flag, while the rest of the female members will create el Corte de Honor, having as a distinction a tricolor sash with the colors of the Valencian flag. ${ }^{2}$ (Reglamento Fallero 2002: art. 28.2)

Each year women select their representatives and among these one is appointed as la Fallera Mayor, to be the maximum representative of the festivity, together with a group that is considered her court of honor. She receives the keys of the city during the inauguration of las Fallas (la Crida), as a symbol of the falleros taking charge of the city during las Fallas period.

The election of la Fallera Mayor poses another important issue - the economic reality of the festivity, and the exclusion of those without financial capacity. The participation in the festival, in which the community of los falleros repeats the squandering so heavily criticized by them in their sculptures (Lisón Tolosana 2004: 119), is directly related to the financial means possessed both by the comisión fallera, and the falleros or falleras themselves. A woman who decides to participate in the contest must be aware of the necessity of having several dresses, the cost of which is very high, as female attire is worth several thousands of euros (the price varies depending on the fabric and the jewelry). This simple fact impedes the possibility of participation in the contest by all falleras.

The economic reality is important not only in the context of the attire, but also in participating in the community, as there are quotas that permit to finance the events related to the activities of the group that should be paid all year long 
by every member of a falla. Nevertheless, regardless of the financial burden, whole families participate in the agenda of las Fallas. It is an important part of the Valencian identity and the participation in the festivities is a crucial agent in the process of shaping social relationships within their community.

\section{CONCLUSION}

El traje fallero was standardized as a symbol of Valencian identity in the 20th century. Further on it underwent several changes in agreement with temporary fashion, and nowadays the collection of historic elements from different epochs and different social groups mixed with contemporary necessities has created a garment that is considered traditional and is required to be worn during the festivities. This creates curious situations when participants wearing attires based on historically accurate recreations are excluded as not wearing the appropriately traditional costume. The necessity of recognizing two different types of garments - el traje fallero and el traje histórico - by the fiesta administration has arisen, as el traje fallero is a part of invented and still changing codification. Nevertheless, the las Fallas garments, however not traditional with their historic and contemporary elements, should be considered an important part of contemporary Valencian culture, presenting the complexity of the evolution of festive attire. 


\section{NOTES}

1 Original text: 1 . Con el fin de dar el mayor realce y esplendor a los actos y desfiles falleros, las Comisiones velarán porque en la fiesta de las Fallas se utilice la indumentaria fallera y valenciana tradicional, diferenciando la utilizada por el hombre de la usada por la mujer valenciana y fallera: a) El fallero utilizará el traje instituido en el IV Congreso General Fallero o cualquier traje tradicional valenciano. b) La fallera deberá lucir el tradicional traje de valenciana. 2. Queda terminantemente prohibida la utilización de prendas que no sean acordes a la indumentaria tradicional fallera expresada anteriormente, asimismo no se permitirá la utilización de prendas masculinas por falleras, en actos oficiales, con independencia del cargo que ocupen. A estos efectos, se considera el blusón o blusa prenda masculina.

2 Original text: La Fallera Mayor será la única mujer que ejercerá la representación honorífica de la Comisión de Falla en los actos propios y oficiales. Su designación será de competencia exclusiva de la Junta General, correspondiéndole ocupar el lugar protocolario preferente en toda actividad de la Comisión. Usará como distintivo propio la banda tradicional confeccionada en cinta con los colores de la bandera nacional, mientras que el resto de componentes femeninas formarán la Corte de Honor, siendo su banda distintiva confeccionada con cinta tricolor de la Señera valenciana.

\section{REFERENCES}

Ariño Villarroya, Antonio 1990. Fiesta y sociedad en la Valencia contemporánea. [Festivity and Society in Contemporary Valencia.] Diss. (PhD Thesis). Valencia: Universitat de Valencia. Available at https://www.academia.edu/12657690/Fiesta_y_sociedad_ en_la_Valencia_contempor\%C3\%A1nea, last accessed on October 6, 2016.

Ariño Villarroya, Antonio 1992. La ciudad ritual: La fiesta de las Fallas. [The Ritual City: The Festivity of las Fallas.] Barcelona: Anthropos.

Fernández Montes, Matilde (coord.) 1996. Etnología de las Comunidades Autonómas. [Ethnology of the Autonomous Regions.] Madrid: Ediciones Doce Calles.

Ferrandis Mas, Vicent 1983. Indumentaria valenciana: El vestido del hombre 1787-1840. [Valencian Attire: Male Clothing in 1787-1849.] Torrens, No. 2, pp. 115-161. Available at http://ru.calameo.com/read/0010678169a78573596e5, last accessed on October 6, 2016.

Hobsbawm, Eric \& Ranger, Terence (eds.) 1992 [1983]. The Invention of Tradition. Cambridge: Cambridge University Press. Available at http://psi424.cankaya. edu.tr/uploads/files/Hobsbawm_and_Ranger_eds_The_Invention_of_Tradition. pdf, last accessed on October 6, 2016.

Liceras Ferreres, María Victoria 2011. Indumentaria Valenciana siglo XVIII-XIX. [The Valencian Attire in the 18th-19th Centuries.] Valencia: Editors Carena.

Lisón Tolosana, Carmelo 2004. Invitación a la antropología cultural de España. [Invitation to the Spanish Cultural Antropology.] Madrid: Akal.

Olmedo de Cerdá, María Francisca 2014 [2003]. Callejeando por Valencia. [Walking through the Streets of Valencia.] Valencia: Carena Editors. 
Puerta Ecribano, Ruth de la 2002. Indumentaria popular del labrador en la huerta de Valencia (siglos XVIII-XIX). [Popular Attire of the Farmer of Valencia (18th-19th Centuries).] Annales de Museo Nacional de Antropología, No. 9, pp. 171-208. Available at https://dialnet.unirioja.es/servlet/articulo?codigo $=1988083$, last accessed on October 6, 2016.

Reglamento Fallero 2002. VIII Congreso General Fallero. Mayo - Junio 2001. Aprobado por la Comisión de Cultura el 20 de Febrero 2002 Aprobado por el Pleno Municipal el 22 de Febrero 2002. Available at http://www.fallas.com/index.php/es/main-jcf-es/ main-reglamento-fallero-es/125-reglamento-fallero, last accessed on October 23, 2016. 